\title{
Compliance and Efficacy of Hand Rubbing during In-Hospital Practice
}

\author{
Oguz Karabay ${ }^{a}$ Irfan Sencan ${ }^{b}$ Idris Sahin ${ }^{b}$ Hacer Alpteker $^{c}$ Arzu Ozcan $^{c}$ \\ Sukru Oksuz ${ }^{\mathrm{b}}$ \\ Department of Infectious Diseases and Clinical Microbiology, Faculty of Medicine, ${ }^{a}$ Abant Izzet Baysal \\ University; ${ }^{b}$ Duzce Faculty of Medicine, and ${ }^{\mathrm{c}}$ Nursing High School, Abant Izzet Baysal University, Bolu, Turkey
}

\section{Key Words}

Hand rubbing $\cdot$ Hand washing $\cdot$ Hospital infection

\begin{abstract}
Objective: To compare alcohol-based hand rubbing with hand washing using antimicrobial soap regarding antimicrobial efficacy and compliance with routine practice in hospital and intensive care units. Subjects and Methods: From February to June 2003, 35 nurses were randomly selected from a nursing staff of 141 and divided into two groups: hand rubbing and hand washing groups. Hand cultures were obtained before and after health care procedures. The nurses were observed on days 1, 7 and 14 of the study, in order to determine compliance and efficacy of the hand hygiene methods. Results: A total of 368 routine patient care activities were observed during the study period. Hand rubbing with alcohol-based solutions significantly reduced the bacterial contamination of the hands of the nurses more than hand washing with an antimicrobial soap (54 and $27 \%$, respectively; $p<$ 0.01). Compliance was also better in the hand rubbing group than in the hand washing group (72.5 and $15.4 \%$, respectively; $p<0.001)$. Compliance with hand rubbing was markedly lower among the nurses who had experi-
\end{abstract}

ence of more than 3 years in hospital practice. Both hand rubbing and hand washing compliance were poorer among nurses working in intensive care units than among nurses working in the other hospital wards. Generally, after taking off gloves, nurses preferred hand washing to hand rubbing. Conclusion: These data indicate that alcohol-based hand rubbing reduces mean bacterial counts on the hands of nurses more effectively than hand washing with antimicrobial soaps, and compliance rates with hand rubbing were also higher than with hand washing. Nevertheless, the compliance with hand rubbing was markedly lower in more experienced nurses.

Copyright (C) 2005 S. Karger AG, Basel

\section{Introduction}

Hospital infections cause prolonged hospitalization and consumption of resources as well as increased morbidity and mortality [1]. Nosocomial pathogens are sometimes transmitted from patient to patient through the hands of healthcare workers [2]. The pathogens on the hand can be divided into transient and resident flora [3]. The transient flora appears to be the more important

\section{KARGER}

Fax +4161306 1234 E-Mail karger@karger.ch www.karger.com 
cause of nosocomial infections. The hands of the healthcare workers are frequently contaminated by direct contact during routine patient care or while touching a contaminated surface or device. Multiple epidemics have been reported due to contaminated hands of healthcare workers $[4,5]$. Hand hygiene is therefore considered as the most important, cheapest and most effective infection control measure in preventing horizontal transmission of nosocomial pathogens [6].

Nevertheless, compliance with hand washing among healthcare workers is only about 40-50\% [7]. Increased patient workload, decreased staffing, limited time, long distances to sinks, belief that use of glove obviates the need for hand hygiene and ignorance of or disagreement with guidelines and protocols have all contributed to poor compliance with hand hygiene and other routine infection control measures $[8,9]$. Infection control is rarely taught in medical and nursing schools, and poor hand washing practices may be learnt from peers at the bedside $[10,11]$. In order to overcome the compliance problem, alternative hand hygiene methods have been developed. During routine patient care, hand rubbing with alcoholbased solution is found to be more effective in reducing contamination than hand washing with antiseptic soap [12]. Moreover, alcohol-based hand rubbing provides effective antisepsis, does not require the use of sinks and is easier than using soap [13].

In daily practice compliance to hand washing is low $[9,10]$ and the reasons for low compliance have not yet been defined in developing countries probably due to limited studies on hand hygiene. Therefore the aim of this study was to compare alcohol-based hand rubbing and hand washing with an antimicrobial soap with regards to both antimicrobial efficacy and compliance.

\section{Subjects and Methods}

\section{Setting and Participants}

This study was undertaken in Duzce Medical School Hospital, Bolu, Turkey, with a healthcare staff of 415 and of these, 141 are nurses. The hospital has medical and surgical units with 200 regular ward beds and 10 intensive care unit (ICU) beds. The hospital serves a population of approximately 500,000.

This study was performed in the ICU, and in the Internal Medicine and Surgical Units from February 1 to June 17, 2003 involving 35 nurses selected randomly from the nursing staff of 141 . Three nurses were excluded because 2 did not agree with the compliance requirement and 1 had surgery. The remaining 32 (29 female and 3 male, $25.4 \pm 4.1$ years, range 19-37 years) were divided equally into hand rubbing and hand washing groups. The age, duration of employment and units were obtained from the data base. Six of the nurses worked in ICUs, 12 in the Internal Medicine Wards and the remaining 14 in Surgical Units. A total of 160 routine patient care activities were observed in the hand rubbing group and 208 in the hand washing group.

The term 'hand hygiene' in this study is defined as either hand washing or antiseptic hand rub. Participants were informed about the required hand washing and alcohol-based hand rubbing processes. The predefined indications for hand rubbing or hand washing are given in table 1 . Hand washing was performed with Klorheksol $^{\mathrm{TM}}$ (2\% chlorhexidine gluconate, $1 \%$ isopropyl alcohol and poncean 4P, Merkez Laboratuari, Ankara, Turkey). Hand rubbing was performed with Sterisol ${ }^{\mathrm{TM}}$ (70\% ethanol, 10\% isopropyl alcohol, 1\% butyl alcohol with glycerin, Sterisol System, Sweden).

The hand washing process included wetting hands with water; applying an amount of the product to the hands as recommended by the manufacturer; rubbing hands together vigorously for at least $15 \mathrm{~s}$, covering the surfaces of the hands and fingers; rinsing hands with water and drying thoroughly with a disposable towel and finally using a towel to turn off the faucet.

The hand rubbing process included applying manufacturer's recommended volume of the Sterisol product to the palm of one hand and rubbing both hands together, covering the surfaces of hands and fingers until hands were dry (this procedure took 15$25 \mathrm{~s})$.

Sterisol was not used when hands were visibly dirty or contaminated with proteinaceous materials. In this situation the participants were requested to wash their hands thoroughly with either a nonantimicrobial soap and water or an antimicrobial soap and water [8].

\section{Microbiological Sampling and Evaluation}

Samples were taken from the palms and fingertips of the subjects' dominant hands before and a few minutes following hand hygiene. Fingertips and palms were pressed on an agar plate that included 5\% sheep blood. The plates were then incubated for $24 \mathrm{~h}$ at $37^{\circ} \mathrm{C}$ and total bacterial counts were expressed as colony-forming units (cfu). Microbiologists who evaluated the plates were blinded to the hand hygiene techniques. Isolated microorganisms were identified according to classical microbiological methods [12, 13].

\section{Investigation of Compliance}

All participants were volunteers and gave written informed consent. They were informed about the observation process, but not the time schedule of the observations or indications. One of the investigators (O.K.) gave a 2-hour teaching session to all nurses on the importance of hand hygiene and its role in nosocomial infections prior to conducting the study. Brochures for both hand washing and hand rubbing techniques as described by Coignard et al. [14] were mounted near sinks and related apparatus during the observational period.

An infectious diseases specialist (I.S.) and infection control nurses (A.O., H.A.) observed the hand hygiene behaviors. The participants were observed on days 1, 7 and 14 during the busiest times (10-11 a.m. and 2-3 p.m.) of the day for routine care activities. Participants were considered to be noncompliant when they did not perform hand washing or rubbing in accordance with one or more of the indications listed in table 1 . The nurses were further subdivided into those with more or less than 3 years of experience to determine compliance rates. 


\section{Statistical Evaluation}

The characteristics of the study groups were evaluated by a twosample $t$ test and Student's $t$ test for each continuous variable and either a chi-square or a Fisher exact test for categorical variables. Epi-Info 6.0 (Centers for Disease Control and Prevention, Atlanta, USA) was used to perform the univariate analysis. Afterwards, multivariate analysis was applied to parameters (hand hygiene, unit, working experience) determined as significant for compliance with univariate analysis. Multivariate analysis was performed using the Statistics for Social Sciences (SPSS 10.0 for Windows) program. A $\mathrm{p}$ value of $<0.05$ was accepted as significant.

Table 1. Indications for hand hygiene

Before direct contact with the patient

After contact with the patient (when measuring pulse or blood pressure, lifting the patient)

After contact with body fluids or excretions, mucous membranes, non-intact skin, and wound dressings whether or not hands are visibly soiled

After touching a 'dirty' body site and before touching a 'clean' body site during patient care

After contact with inanimate objects (including medical equipment) in the immediate vicinity of the patient

After removing gloves from the hands

Before and after eating, after using the restroom (hand washing with a nonantimicrobial soap and water or with an antimicrobial soap and water)

\section{Results}

Mean bacterial counts $(279 \pm 76$ vs. $251 \pm 73 \mathrm{cfu} / \mathrm{ml})$ in the two groups were similar before the hand hygiene was performed ( $p>0.05)$, but after the mean bacterial counts were $204 \pm 75$ and $102 \pm 32 \mathrm{cfu} / \mathrm{ml}$ in the hand washing and hand rubbing groups, respectively $(\mathrm{p}<$ 0.01).

Compliance rates of the hand hygiene methods are given in table 2. In univariate analysis, compliance rates were 15.4 and $72.5 \%$ in the hand washing and the hand rubbing group, respectively $(\mathrm{p}<0.0001)$. In ICUs, compliance rates with hand washing and hand rubbing were 10.0 and $28.8 \%$, respectively $(\mathrm{p}<0.01)$; in other hospital wards, the corresponding compliance rates were 17.0 and $89.5 \%(\mathrm{p}<0.0001)$. In the multivariate analysis, compliance of nurses in ICUs to hand rubbing was found to be significantly less than in other hospital wards (F: 94.11, $\mathrm{p}<0.01)$. However, in the hand washing group, there was no significant difference between ICUs and other hospital wards (table 3 ).

Compliance rates for the nurses with less than 3 years' experience were significantly higher in the hand rubbing group $(87.7 \%)$ than in the hand washing group $(12.5 \%$, $\mathrm{p}<0.0001)$. In the more experienced group, compliance
Table 2. Compliance rates according to the hand hygiene methods

\begin{tabular}{|c|c|c|c|}
\hline Parameters & $\begin{array}{l}\text { HW group } \\
\mathrm{n}(\%)\end{array}$ & $\begin{array}{l}\text { HR group } \\
\mathrm{n}(\%)\end{array}$ & $\mathrm{p}$ value \\
\hline \multicolumn{4}{|c|}{ Total compliance with hand hygiene } \\
\hline$($ HW 208, HR 160, n = 368) & $32(15.4)$ & $116(72.5)$ & 0.0001 \\
\hline \multicolumn{4}{|l|}{ Compliance with wearing gloves } \\
\hline$(\mathrm{HW} 208, \mathrm{HR} 160, \mathrm{n}=368)$ & $85(40.9)$ & $46(28.7)$ & 0.016 \\
\hline \multicolumn{4}{|l|}{ Compliance in ICU nurses } \\
\hline$(\mathrm{HW} 50, \mathrm{HR} 45, \mathrm{n}=95)$ & $5(10.0)$ & $13(28.8)$ & 0.018 \\
\hline \multicolumn{4}{|l|}{ Compliance in regular nurses } \\
\hline$($ HW 158, HR 115, n = 273) & $27(17.0)$ & $103(89.5)$ & 0.0001 \\
\hline \multicolumn{4}{|c|}{$\begin{array}{l}\text { Compliance with hand hygiene after gloves } \\
\text { taken off }\end{array}$} \\
\hline$(\mathrm{HW} 85, \mathrm{HR} 46, \mathrm{n}=131)$ & $34(40.0)$ & $6(13.0)$ & 0.001 \\
\hline \multicolumn{4}{|c|}{ Compliance according to working experience } \\
\hline $\begin{array}{l}(\mathrm{HW} 137, \mathrm{HR} 114, \mathrm{n}=251) \\
\geq 4 \text { years }\end{array}$ & $17(12.5)$ & $100(87.7)$ & 0.0001 \\
\hline$(\mathrm{HW} 71, \mathrm{HR} 46, \mathrm{n}=117)$ & $15(21.1)$ & $16(34.7)$ & 0.12 \\
\hline \multicolumn{4}{|l|}{ Dermatitis } \\
\hline$(\mathrm{HW} 0, \mathrm{HR} 1, \mathrm{n}=1)$ & 0 & $1(0.6)$ & $\mathrm{NA}^{*}$ \\
\hline
\end{tabular}


Table 3. Multivariate analysis results according to hand hygiene methods

\begin{tabular}{|c|c|c|c|c|c|c|}
\hline \multirow[t]{3}{*}{ Independent variables } & \multicolumn{6}{|c|}{ Dependent variables } \\
\hline & \multicolumn{3}{|c|}{ hand rubbing compliance } & \multicolumn{3}{|c|}{ hand washing compliance } \\
\hline & Rsq & $\mathrm{F}$ & $\mathrm{p}$ & Rsq & $\mathrm{F}$ & $\mathrm{p}$ \\
\hline Unit (ICU nurses/regular nurses) & 0.373 & 94.11 & 0.000 & 0.017 & 3.64 & 0.058 \\
\hline $\begin{array}{l}\text { Working experience } \\
\quad(\leq 3 \text { years } />3 \text { years })\end{array}$ & 0.084 & 14.42 & 0.000 & 0.013 & 2.74 & 0.099 \\
\hline
\end{tabular}

with hand rubbing was reduced from 87.7 to $34.7 \%$, while in the hand washing group compliance increased from 12.5 to $21.1 \%$. No statistically significant difference was found between rubbing and washing $(p>0.05)$.

Compliance with hand hygiene after gloves were taken off was more frequent in the hand washing group than in the hand rubbing group ( 40 vs. $13 \%, \mathrm{p}<0.01$ ). Dermatitis was absent in the hand rubbing group, but was present in 1 subject in the hand washing group.

\section{Discussion}

Healthcare workers are aware that pathogens may be transmitted from one patient to another while caring for the patients. For nearly 150 years it has been shown that hand washing before and after contact with a patient is the most effective measure of preventing contamination [15] as it has been shown in many studies that increasing compliance decreases hospital infection rates [9-16].

In the present study, reduction in total bacterial count was more in the hand rubbing group than in the hand washing group $(\mathrm{p}<0.01)$, similar to previous studies [12, 13]. A possible explanation is that hand washing with antimicrobial soap may not remove all transient microorganisms due to the short duration of hand washing $(<15 \mathrm{~s})$. Compliance with hand hygiene was more in the less experienced nurses. Newly recruited nurses undertook orientation courses where hand hygiene was emphasized. Another plausible explanation for low rates of compliance among the more experienced nurses may be due to lack of continuing education. It is therefore apparent that continuing education is important and that hand hygiene ought to be emphasized.

In the univariate analysis, the significant difference in compliance between hand washing and rubbing could be due to time limitation and intolerance towards or allergic reactions to the hygiene methods in ICU workers [17]. The relatively high compliance rate for hand rubbing in
ICUs may be related to the practical fact that it is faster and does not require use of sink, soap, and towel. This finding is consistent with other studies $[5,17,18]$, while in the multivariate analysis, the compliance rates were lower in the nurses working in ICUs than the other hospital wards probably due to low staff-to-patient ratio and excessive use of gloves in ICUs.

Interestingly, the compliance after taking gloves off was lower in the hand rubbing group than in the hand washing group (13 vs. $40 \%$, respectively; $p<0.001)$ mainly because hand rubbing does not remove powder remains. Thus, nurses in the hand rubbing group did not use the alcohol-based hand rub immediately.

\section{Conclusion}

The data indicate that alcohol-based hand rubbing reduces mean bacterial counts on the hands of nurses more effectively than hand washing with antimicrobial soaps, and also that compliance rates with hand rubbing were higher than hand washing, but nurses preferred hand washing after taking off gloves. We therefore recommend the hand rubbing method particularly in developing countries with limited health resources and continuing nursing education that includes hand hygiene.

\section{Acknowledgments}

We would like to thank Ms. Filiz Akbiyik for her technical help and Dr. Hasan Ekerbicer for statistical assistance. 


\section{References}

1 Emmerson AM, Enstone JE, Griffin M: The Second National Prevalence Survey of infection in hospitals: overview of the results. J Hosp Infect 1996;32:175-190.

2 Edmond MB, Wenzel RP: Isolation; in Mandell GL, Dolin R, Benett JE (eds): Principles and Practice of Infectious Diseases. Edinburgh, Churchill Livingstone, 2000, pp 29912995.

-3 Roberts SA, Findlay R, Lang SD: Investigation of an outbreak of multi-drug resistant Acinetobacter baumannii in an intensive care burns unit. J Hosp Infect 2001;48:228-232.

4 El Shafie SS, Alishaq M, Leni Garcia M: Investigation of an outbreak of multidrug-resistant Acinetobacter baumannii in trauma intensive care unit. J Hosp Infect 2004;56:101-105.

$\checkmark 5$ Maury E, Alzieu M, Baudel J, Haram N, Barbut F, Guidet B, Offenstadt G: Availability of an alcohol solution can improve hand disinfection compliance in an intensive care unit. Am J Respir Crit Care Med 2000;162:324-327.
-6 Kollef HM, Fraser JV: Antibiotic resistance in the intensive care unit. Ann Intern Med 2001; 134:298-314.

7 Pittet D, Mourouga P, Perneger TV: Compliance with hand washing in a teaching hospital. Ann Intern Med 1999;20:598-603.

$\checkmark 8$ Boyce JM, Pittet D: Guideline for hand hygiene in health-care settings. Am J Infect Control 2002;30: 1-46.

$>9$ Pittet D: Improving adherence to hand hygiene practice: a multidisciplinary approach. Emerg Infect Dis 2001; 7:234-240.

10 Tibballs J: Teaching hospital medical staff to handwash. Med J Aust 1996;164:395-398.

11 Larson E, McGinley KJ, Grove GL, Leyden JJ, Talbot GH: Physiologic, microbiologic and seasonal effects on the skin of health care personnel. Am J Infect Control 1986;14:51-59.

12 Girou E, Loyeau S, Legrand P, Oppein F, Brun-Buisson C: Efficacy of handrubbing with alcohol based solution versus standard handwashing with antiseptic soap: randomised clinical trial. BMJ 2002;325:362-365.
-13 Zaragoza M, Salles M, Gomez J, Bayas JM, Trilla A: Handwashing with soap or alcoholic solutions? A randomized trial of its effectiveness. Am J Infect Control 1999;27:258-261.

14 Coignard B, Grandbastien B, Berrouane Y, Krembel C, Queverue M, Salomez JL, Martin G: Handwashing quality: impact of a special program. Infect Control Hosp Epidemiol 1998: 19:510-513.

15 Heseltine P: Why don't doctors and nurses wash their hands? Infect Control Hosp Epidemiol 2001;22:199-200.

16 Wewalka G, Rotter M, Koller W, Stanek G: Comparison of efficacy of 14 procedures for the hygienic disinfection of hands. Zentralbl Bakteriol 1977; 165:242-249.

17 Sproat LJ, Inglis TJ: A multicenter survey of hand hygiene practice in intensive care units. J Hosp Infect 1994;26:137-148.

18 Eggimann P, Pittet D: Infection control in the ICU. Chest 2001;120:2059-2093. 